\title{
The Urgency of Pancasila Values as a Basis of Science and Environment Development
}

\section{Pranoto}

Fakultas Matematika dan IImu Pengetahuan Alam Universitas Sebelas Maret pakpranoto@gmail.com

\section{Article History}

accepted 23/03/2021

approved 10/04/2021

published 20/04/2021

\begin{abstract}
Entering the era of the industrial revolution 4.0, the order of life refers to the world of the digital industry, as well as the fields of Science and the Environment. The industrial revolution 4.0 requires each individual to run fast to develop literacy skills in technology, data and human resources. These three things become the basic capital in developing various self-competencies for each individual. The development and progress of Science and the Environment today cannot be separated from the mastery of these three literacies. The development of Science and the Environment that is not balanced with the foundation of the nation's fundamental foundation, will in fact contribute more to negative than positive influences. Misuse of Science and the Environment will threaten the existence of human life in the future. Therefore, weapons are needed to ward off various negative possibilities for the development of Science and the environment, one of which is Pancasila. Pancasila powers are not only limited to being the basis of the state, guidelines for life, and unifying the Indonesian nation, but also as a guiding star in all aspects of life, including the development of Science and the Environment. The basic values contained in Pancasila must serve as basic guidelines in the development of Science and the Environment. Pancasila is used as the basis for the development of Science and the Environment and is expected to have a broad impact on the benefit of the life of the Indonesian nation. Science and the Environment may develop and advance, but must be balanced with maintaining and implementing the noble values of the nation's ideology in all aspects of the life of the nation and state.
\end{abstract}

Keywords: Pancasila values, science and the environment

\section{Abstrak}

Memasuki era revolusi industri 4.0, tatanan keHidupan mengacu pada dunia industri digital, begitu halnya bidang Sains dan Lingkungan Hidup. Revolusi industri 4.0 menuntut setiap individu berlari cepat untuk menumbuhkembangkan kemampuan literasi teknologi, data, dan sumber daya manusia. Ketiga hal tersebut menjadi modal dasar dalam pengembangan berbagai kompetensi diri setiap individu. Perkembangan dan kemajuan Sains dan Lingkungan Hidup saat ini juga tidak terlepas dari penguasaan ketiga literasi tersebut. Perkembangan Sains dan Lingkungan Hidup yang tidak diimbangi dengan pijakan landasan fundamental bangsa, justru akan lebih banyak menyumbangkan pengaruh negatif dari pada positif. Penyalahgunaan Sains dan Lingkungan Hidup akan mengancam eksistensi Hidup manusia di masa yang akan datang. Oleh karena itu, diperlukan senjata untuk menangkal berbagai kemungkinan negatif perkembangan Sains dan Lingkungan hidup, salah satunya adalah Pancasila. Kesaktian Pancasila tidak hanya sebatas sebagai dasar negara, pedoman Hidup, dan pemersatu bagi bangsa Indonseia, tetapi juga dijadikan sebagai bintang penuntun dalam segala aspek keHidupan, termasuk pengembangan Sains dan Lingkungan Hidup. Nilai-nilai dasar yang terkandung dalam Pancasila harus dijadikan sebagai pedoman pokok dalam pengembangan Sains dan Lingkungan Hidup. Pancasila dijadikan sebagai dasar pengembangan Sains dan Lingkungan Hidup diharapkan memberi dampak luas pada kemaslahatan kehidupan bangsa Indonesia. Sains dan Lingkungan Hidup boleh berkembang dan maju, namun harus diimbangi dengan menjaga dan mengimplementasikan nilai-nilai luhur ideologi bangsa di seluruh aspek kehidupan berbangsa dan bernegara.

Kata kunci: nilai-nilai Pancasila, sains dan lingkungan hidup hidup

Social, Humanities, and Education Studies (SHEs): Conference Series p-ISSN 2620-9284 


\section{PENDAHULUAN}

Pengamalan nilai-nilai pancasila juga banyak tidak sesuai dengan kondisi dan situasinya. Baik dalam konteks, pancasila dalam lintas sejarah, perkembangan pancasila, pancasila sebagai idelologi negara dan sistem filsafat, sebagai etika politik, dalam hubungan agama, pancasila sebagai paradigma dalam kehidupan berbangsa, bernegara, dan bermasyarakat, serta pancasila sebagai dasar nilai pengembangan ilmu pengetahuan.

Disamping itu, semakin rendahnya kesadaran generasi bangsa akan pentingnya pengamalan nilai-nilai pancasila dalam berbagai aspek kehidupan, bahkan dalam kerangka pemikiran yang ekstrem tidak sedikit yang mempertentangkan finalnya pancasila sebagai ideologi bangsa dan negara kesatuan Republik Indonesia.

Dikalangan pelajar dan mahasiswa, minimnya pengamalan nilai-nilai pancasila menjadi cikal bakal merebaknya aliran-aliran ekstremisme yang berakibat pada tindakan-tindakan radikal yang dibungkus dengan aktivitas ilmiah untuk memporak porandakan sendi-sendi kehidupan berbangsa dan bernegara. Oleh karena itu, pendidikan pancasila perlu diajarkan diperguruan tinggi sebagai bagian dari motivasi dan support untuk meningkatkan nilai-nilai pancasila dalam keHidupan masyarakat dan menjadi kunci pencegahan terhadap ideologi-ideologi yang menyimpang dari nilai-nilai yang termaktub dalam sila-sila pancasila.

\section{METODE}

Apakah nilai-nilai Pancasila sudah secara sistematis "terlupakan" dalam khazanah kehidupan masyarakat? Jawabannya akan menjadi perdebatan, tetapi faktafakta di tengah masyarakat bisa menjadi bukti konkrit bahwa dasar bernegara ini cenderung hanya menjadi slogan di dinding ataupun sekedar bahan pelajaran di sekolah-sekolah. Hapal Pancasila, tapi sesama anak bangsa saling serang, korupsi jalan terus, agama dijadikan sumber konflik, parpol saling sikut dan kongkalingkong, persatuan diabaikan dan kekayaan alam hanya milik segelintir orang. Begitulah fenomenanya di jaman now.

Pancasila seakan tercerabut dari masyarakatnya sendiri, tercerabut dari orangorang yang sudah bersepakat untuk mengambilnya sebagai jalan Hidup. Kalau memang sudah terlepas dari akar, dari tempat berpijak, maka tidak lagi menapak tanah, publik sudah menjadi publik di awang-awang. Tak tahu lagi realitas, tak terikat lagi dengan sekitarnya. Bersenang-senang dengan segala yang bersifat konsumerisme, lupa akan tanah tempat berpijak.

Pada konteks ini komunitas yang tak menapak tanah adalah orang-orang yang tak lagi paham akan jernihnya air di sungai, gelepar ikan di sela bebatuan, kuningnya padi di musim panen yang bercengkerama dengan pipit terbang rendah, tak paham lagi akan pekatnya air rawa gambut tempat berlayar biduk nelayan pencari purun. Yang tampak di depan mata hanyalah hamparan alam yang bisa menjadi sumber pundi-pundi, memandang lahan sebagai sumber kekayaan pribadi. Itulah publik yang tak lagi berpijak, orang-orang jaman now.

Melepaskan masyarakat dari hakekat alam semesta atau dari keterhubungannya dengan ekosistem yang lebih besar, sama saja dengan melepaskannya dari pondasi bernegara. Pancasila sudah merangkum semua dasardasar kehidupan, aspek ketuhanan, kemanusiaan, persatuan, permusyawaratan dan keadilan sosial untuk semua makhluk. Sudah ditegaskan semua itu, yang intinya menyatakan bahwa kehidupan ini adalah ekosistem yang besar. Dalam bahasa lain, keHidupan ini terdiri atas geopolitik dan geospasial yang harus dipahami sebagai sebuah kesatuan. Satu sudut pandang yang berangkat dari rasa kepentingan semua makhluk secara bersama-sama. Wawasan nusantara begitulah bahasa yang kerap didengar. 
Oleh karenanya, kalau sekarang banyak mendengar dan bahkan menderita karena bencana yang tak juga hilang, seperti pekatnya kabut asap gara-gara kebakaran lahan atau derasnya banjir di musim hujan, pada dasarnya sudah menjadi bagian dari publik yang tak dekat lagi dengan dasar bernegara. Bencana bukan karena faktor alam semata, sangat kecil kemungkinannya, tapi justru dominan karena ulah manusia. Manusialah yang membabat hutan, membakar lahan dan manusia juga yang kemudian menderita serta dipusingkan dengan hal itu. Manusia yang melepaskan diri dari tempatnya berpijak dan itu adalah manusia yang tidak menjiwai Pancasila.

Terhadap terjadinya kerusakan lingkungan, termasuk kebakaran hutan dan lahan (karhutla), sudah cukup banyak usaha yang dilakukan, namun hampir bisa dipastikan semua tak tuntas dalam menyelesaikan masalah. Kecenderungan hanya penawar rasa sakit, sikap cepat dalam tanggap darurat tapi minim pada mitigasi. Bencanapun terus berulang.

Siapakah yang berada di sekitar kebakaran hutan dan lahan tersebut? Masyarakat desa, pemerintah desa, pemerintah kabupaten/kota dengan beragam SKPD nya, dan perusahaan perkebunan. Itulah komponen yang terkait langsung, yang paling banyak beraktifitas dan memiliki tanggungjawab langsung terhadap keadaan alam setempat. Andai setiap musim kemarau masih juga terjadi karhutla maka bisa dipertanyakan ada apa yang terjadi sebenarnya. Jangan-jangan mereka justru menjadi penyebab masalah alih-alih penyelesai masalah.

Begitupun, saat musim hujan, banjir selalu datang dan selalu disibukkan dengan soal dapur darurat, tim penanggulangan, sarana prasarana dan seterusnya. Bencana seakan menjadi proyek tahunan yang harus selalu masuk dalam mata anggaran. Bukan antisipasi tapi keyakinan bahwa bencana itu pasti datang.

Apabila mau menyelesaikan masalah, lihatlah pada akar persoalan. Saya bisa pastikan bahwa akar masalah adalah karena melupakan dasar bernegara, mengabaikan Pancasila sebagai sesuatu yang konkrit. Tidak menjadikan Pancasila sebagai sesuatu yang penting, dan melepaskan Pancasila dari keHidupan sehari-hari. Derita saat bencana terjadi, hanya ekses saja dari semua hal itu.

Pentingnya Pancasila sebagai dasar pengembangan sains dan teknologi dapat ditelusuri ke dalam hal-hal sebagai berikut; Pertama, pluralitas nilai yang berkembang dalam kehidupan bangsa Indonesia dewasa ini seiring dengan kemajuan iptek menimbulkan perubahan dalam cara pandang manusia tentang kehidupan. Hal ini membutuhkan renungan dan refleksi yang mendalam agar bangsa Indonesia tidak terjerumus ke dalam penentuan keputusan nilai yang tidak sesuai dengan kepribadian bangsa. Kedua, dampak negatif yang ditimbulkan kemajuan sains terhadap lingkungan hidup berada dalam titik nadir yang membahayakan eksistensi hidup manusia di masa yang akan datang.

Oleh karena itu, diperlukan tuntunan moral bagi para ilmuwan dalam pengembangan sains dan lingkungan hidup di Indonesia. Ketiga, perkembangan iptek yang didominasi negara-negara Barat dengan politik global ikut mengancam nilai-nilai khas dalam kehidupan bangsa Indonesia, seperti spiritualitas, gotong royong, solidaritas, musyawarah, dan cita rasa keadilan. Oleh karena itu, diperlukan orientasi yang jelas untuk menyaring dan menangkal pengaruh nilai-nilai global yang tidak sesuai dengan nilai-nilai kepribadian bangsa Indonesia.

Pancasila sebagai sumber nilai, kerangka berpikir serta asas moralitas bagi pembangunan sains dan lingkungan hidup. 


\section{HASIL DAN PEMBAHASAN}

Pancasila telah dijadikan dasar nilai bagi pengembangan Sains dan Lingkungan Hidup demi kesejahteraan Hidup masyarakat Indonesia. Pengembangan Sains dan Lingkungan Hidup sebagai hasil budaya masyarakat Indonesia harus didasarkan pada nilai moral ketuhanan dan kemanusiaan yang adil dan beradab. Pada dasarnya sila-sila pada Pancasila merupakan sumber nilai, kerangka pikir, dan dasar moralitas bagi pengembangan Sains dan Lingkungan Hidup Sehingga, silasila dalam Pancasila menunjukkan sistem etika dalam pengembangan Sains dan Lingkungan Hidup. Berikut adalah penjabaran sila- sila Pancasila yang dijadikan sebagai pedoman dalam pengembangan Sains dan Lingkungan Hidup yang dikemukakan oleh Kaelan (2000).

Pertama, Sila Ketuhanan Yang Maha Esa, mengimplementasikan ilmu pengetahuan, mencipta, perimbangan antara rasional dengan irrasional, Sains dan Lingkungan Hidup tidak hanya memikirkan apa yang ditemukan, dibuktikan, dan diciptakan, tetapi juga dipertimbangkan tujuannya dan akibatnya, apakah merugikan manusia dengan sekitarnya atau tidak. Pengolahan diimbangi dengan pelestarian. Sila pertama menempatkan manusia di alam semesta bukan sebagai pusatnya melainkan sebagai bagian yang sistematik dari alam yang diolahnya.

Kedua, Sila Kemanusiaan yang adil dan beradab, memberikan dasar-dasar moralitas bahwa manusia dalam mengembangkan Sains dan Lingkungan Hidup haruslah secara beradab. Sains dan Lingkungan Hidup adalah bagian dari proses budaya manusia yang beradab dan bermoral. Oleh karena itu, pembangunan Sains dan Lingkungan Hidup harus didasarkan pada hakikat tujuan demi kesejahteraan umat manusia Sains dan Lingkungan Hidup harus dapat diabdikan untuk peningkatan harkat dan martabat manusia, bukan menjadikan manusia sebagai makhluk yang angkuh dan sombong akibat dari penggunaan Sains dan Lingkungan Hidup

Ketiga, Sila Persatuan Indonesia, memberikan kesadaran kepada bangsa Indonesia bahwa rasa nasionalisme bangsa Indonesia akibat dari sumbangan Sains dan Lingkungan Hidup, dengan Sains dan Lingkungan Hidup persatuan dan kesatuan bangsa dapat terwujud dan terpelihara, persaudaraan dan persahabatan antar daerah di berbagai daerah terjalin karena tidak lepas dari faktor kemajuan Sains dan Lingkungan Hidup. Oleh karena itu, Sains dan Lingkungan Hidup Pharus dapat dikembangkan untuk memperkuat rasa persatuan dan kesatuan bangsa dan selanjutnya dapat dikembangkan dalam hubungan masyarakat Indonesia dengan masyarakat internasional.

Keempat, Sila Kerakyatan yang dipimpin oleh hikmah kebijaksanaan dalam permusyawaratan/perwakilan, mendasari pengembangan Sains dan Lingkungan Hidup secara demokratis. Hal ini berarti bahwa setiap ilmuwan haruslah memiliki kebebasan untuk mengembangkan Sains dan Lingkungan Hidup. Selain itu, dalam pengembangan Sains dan Lingkungan Hidup setiap ilmuwan juga harus menghormati dan menghargai kebebasan orang lain dan harus memiliki sikap yang terbuka artinya terbuka untuk dikritik, dikaji ulang maupun dibandingkan dengan penemuan teori lainnya.

Kelima, Sila Keadilan sosial bagi seluruh rakyat Indonesia. Kemajuan Sains dan Lingkungan Hidup harus dapat menjaga keseimbangan keadilan dalam keHidupan kemanusiaan, yaitu keseimbangan keadilan dalam hubungannya dengan dirinya sendiri, manusia dengan Tuhannya, manusia dengan manusia lain, manusia dengan masyarakat bangsa dan negara serta manusia dengan alam lingkungannya.

Bisa dirunutkan, dimana pada sila pertama berbicara tentang Ketuhanan, keyakinan pada Sang Pencipta. Ini adalah pondasi utama yang tak boleh dilupakan. Alam semesta ini adalah ciptaan Sang Khalik, semua agama mengakui itu dan manusia harus menjaga dan merawatnya. Kalau alam tidak dirawat sama saja kita 
tidak mempercayai kuasa Tuhan terhadap itu. Merusak milik Tuhan, sama saja dengan tidak mengakui adanya Tuhan, dan tidak mengakui Tuhan jelas bukan Pancasilais.

Sila kedua, menekankan pada sisi kemanusiaan dengan tekanan keadilan dan keberadaban. Terjadinya peristiwa karhutla sudah sangat jelas meniadakan sisi kemanusiaan, apalagi adil dan beradab. Kalau ada hanya sekelompok orang saja yang punya kuasa terhadap sekian ribu hektar lahan, bisa melakukan apa saja di lahan tersebut, berkilah pula saat kebakaran terjadi, bahkan bereuforia pula sebagai kelompok yang peduli lingkungan, perusahaan dengan CSR terbaik, disitulah rasa keadilan dan kemanusiaan pada sila kedua sudah terganggu.

Tindakan yang menciptakan aspek kemanusiaan terganggu adalah tindakan yang tidak Pancasilais. Begitu pula dengan tindakan yang memberikan akses terhadap munculnya sikap non pancasilais tersebut, termasuk memberi izin secara besar-besaran, apalagi berkongkalingkong dengan izin itu. Apa yang bisa dilakukan? Batasi kepemilikan lahan dan wajibkan pemilik lahan menjaganya.

Sila ketiga, persatuan, yang sangat jelas terhubung dengan pertama dan kedua. Semua kita berada dalam satu hamparan wilayah yang saling berhubungan. Sakit di satu sisi akan jadi gangguan pada semua sisi. Bersatu artinya punya makna saling membutuhkan, saling merasakan, terikat dalam satu rangkaian tak terpisahkan. Kalaulah tindakan yang kita lakukan ternyata menyebabkan munculnya borok dan merusak hubungan dengan pihak lain, kita sudah menganggu persatuan itu. Satu aliran sungai yang berhulu di satu provinsi tapi berhilir ke daerah lain, maka itu harus dipandang satu hamparan, satu landscape. Tak serta merta dikatakan ini bukan urusan saya, karena itu sudah mengganggu rasa persatuan.

Sila keempat, bijaksana dan musyawarah untuk mufakat, adalah point penting untuk mengatakan bahwa seluruh tumpah darah negara ini harus diperlakukan sebaik-baiknya, secara bijaksana untuk kemakmuran, dengan semangat kebersamaan. Itulah mufakat, bukan memaksakan kehendak pada satu keinginan. Tanah, bumi dan kekayaan alam didalamnya adalah milik bersama, perlakukanlah secara bijaksana. Tahu akan dimana air mengalir, dimana pohon akan tumbuh, dimana padi akan ditanam. Tidak justru melihat bahwa semua adalah untuk pabrik, rumah, industri, dan hanya untuk manusia saja. Bermufakatlah, maka kita akan bijaksana dan itu adalah jiwa yang Pancasilais.

Sila kelima, keadilan sosial dan kemakmuran. Ini betul-betul dasar yang mengatakan bahwa semua rakyat Indonesia punya hak yang sama untuk kemakmuran. Kesehatan, kenyamanan, kebahagiaan, ketentraman adalah milik seluruh makhluk, apalagi manusia. Andai hutan kita babat, tanah dikeruk untuk kolam batubara, rawa dikeringkan untuk kebun kelapa sawit dan $\mathrm{HTI}$, maka kebahagiaan dan ketentraman itupun terganggu. Hawa sejuk berganti dengan kering panas. Sungai menjadi kering, ikan mati, gajah masuk kebun, dan harimau memangsa manusia, itulah yang dikatakan mengganggu dan menghambat keadilan sosial. Pancasila dikunci dengan keadilan sosial ini. Oleh karena itu, momen harlah Pancasila sekarang ini, kendati tak dirayakan gegap gempita, setidaknya mari melakukan refleksi, menilai ke dalam dan berkontemplasi, sembari mengkonkritkan Pancasila di semua sisi, terutama soal bencana. Tidak terlambat, tapi sudah semestinya Pancasila itu konkrit dalam kehidupan. Tak bisa dalam skala besar, lingkup kecilpun jadilah. Tak bisa memperbaiki, tidak merusakpun, sudah sangat bagus, dan itu sudah bagian dari Pancasila.

Pancasila sebagai landasan dari etika Sains dan Lingkungan Hidup. Hal pertama yang terkait dengan kedudukan Pancasila sebagai landasan kebijakan pengembangan ilmu pengetahuan mencakup lima hal, yaitu sebagai berikut.

1. Pengembangan ilmu pengetahuan harus menghormati keyakinan religius masyarakat karena dapat saja penemuan ilmu yang tidak sejalan dengan 
keyakinan religious, tetapi tidak harus dipertentangkan karena keduanya mempunyai logika sendiri.

2. IImu pengetahuan ditujukan bagi pengembangan kemanusiaan dan dituntun oleh nilai-nilai etis yang berdasarkan kemanusiaan.

3. Sains dan Lingkungan Hidup merupakan unsur yang "menghomogenisasikan" budaya sehingga merupakan unsur yang mempersatukan dan memungkinkan komunikasi antar masyarakat. Membangun penguasaan Sains dan Lingkungan Hidup melalui sistem pendidikan merupakan sarana memperkokoh kesatuan dan membangun identitas nasional.

4. Prinsip demokrasi akan menuntut bahwa penguasaan Sains dan Lingkungan Hidup harus merata ke semua masyarakat karena pendidikan merupakan tuntutan seluruh masyarakat.

Kesenjangan dalam penguasaan sains dan lingkungan hidup harus dipersempit terus menerus sehingga semakin merata, sebagai konsekuensi prinsip keadilan sosial. Hal kedua yang meletakkan Pancasila sebagai landasan etika pengembangan Sains dan Lingkungan Hidup dapat dirinci sebagai berikut. (a) Pengembangan Sains dan Lingkungan Hidup terlebih yang menyangkut manusia haruslah selalu menghormati martabat manusia, misalnya dalam rekayasa genetik; (b) Sains dan Lingkungan hidup haruslah meningkatkan kualitas hidup manusia, baik sekarang maupun di masa depan; (c) pengembangan Sains dan Lingkungan Hidup hendaknya membantu pemekaran komunitas manusia, baik lokal, nasional maupun global (d) Sains dan Lingkungan Hidup harus terbuka untuk masyarakat; lebih- lebih yang memiliki dampak langsung kepada kondisi hidup masyarakat; (e) Sains dan Lingkungan Hidup hendaknya membantu penciptaan masyarakat yang semakin lebih adil.

Kelima landasan kebijakan Pancasila dalam pengembangan ilmu pengetahuan tersebut dirasa telah mengakomodir seluruh kekhawatiran masyarakat Indonesiaterkait perkembangan Sains dan Lingkungan Hidup di era Revolusi Industri 4.0 ini. Setiap ilmuan, terkhusus yang ada di Indonesia memiliki kewajiban mengembangkan kemampuan ilmiahnya berdasar pada nilai-nilai Pancasila. Hal ini dikarenakan esensi dari pengembangan Sains dan Lingkungan Hidup bukan untuk mendegradasi segala aspek dalam kehidupan manusia melainkan untuk kemajuan bangsa dan manusia itu sendiri.

\section{SIMPULAN}

Pada akhirnya, sangatlah krusial menghadirkan peran Pancasila sebagai rambu-rambu normatif bagi pengembangan sains dan lingkungan hidup di Indonesia pada era Revolusi Industri 4.0. Pengembangan sains dan lingkungan hidup di Indonesia harus berakar pada budaya bangsa Indonesia itu sendiri dan melibatkan partisipasi masyarakat luas. Kelima sila Pancasila merupakan pedoman yang berisikan nilai-nilai fundamental bangsa dalam penyelenggaran kehidupan bangsa dalam segala aspek yang salah satunya adalah pengembangan sains dan lingkungan hidup. Hanyalah sia-sia ketika sains dan ilmu lingkungan dikembangkan tanpa melirik norma- norma yang ada karena justru kerusakan dalam kehidupan bangsalah yang akan terjadi. 
DAFTAR PUSTAKA

Amir, Syarifuddin. 2013. Pancasila As Integration Philosophy of Education and National Character. International Journal of Scientific \& Technology Research.

Volume 2, Issue 1, January 2013

BP-7 Pusat, 1993, Bahan Penataran P-4, Undang-Undang Dasar 1945, Jakarta. Direktorat Pembelajaran dan Kemahasiswaan DIKTI. (2013),Materi Ajar Mata Kuliah Pendidikan Pancasila, Jakarta: DIKTI.

Direktorat Pembelajaran dan Kemahasiswaan DIKTI. (2016), Pendidikan Pancasila. Jakarta: DIKTI.

Joesoef, Daoed, (1987), "Pancasila, Kebudayaan, dan IImu Pengetahuan", dalam Soeroso H. Prawirohardjo, dkk.,

Kaelan, (2000), Pendidikan Pancasila, Edisi Reformasi. Yogyakarta: Paragigma.

Pancasila Sebagai Orientasi Pengembangan IImu, , 2000,Yogyakarta: PT Badan Penerbit Kedaulatan Rakyat.

Pendidikan Pancasila, Edisi Reformasi, ., (1985), Yogyakarta: Penerbit paradigma. Melson, Van, AGM Ilmu Pengetahuan Dan Tanggung Jawab Kita, ., 2001,Jakarta: PT Gramedia, Terjemahan K.Bertens, Judul asli "Wetenschap en Verantwoondelijkheid". Mustansyir, Rizal dan Misnal munir, Filsafat IImu, Yogyakarta: Pustaka Pelajar 